\title{
The St. Louis African American health-heart study: methodology for the study of cardiovascular disease and depression in young-old African Americans
}

Robin R Bruchas ${ }^{1,3}$, Lisa de las Fuentes ${ }^{1,4}$, Robert M Carney², Joann L Reagan ${ }^{1}$, Carlos Bernal-Mizrachi ${ }^{3}$, Amy E Riek ${ }^{3}$, Chi Charles Gu ${ }^{4}$, Andrew Bierhals ${ }^{5}$, Mario Schootman ${ }^{6}$, Theodore K Malmstrom7, Thomas E Burroughs ${ }^{8}$,

Phyllis K Stein ${ }^{1}$, Douglas K Miller ${ }^{9}$ and Victor G Dávila-Román ${ }^{*}$

\begin{abstract}
Background: Coronary artery disease (CAD) is a major cause of death and disability worldwide. Depression has complex bidirectional adverse associations with CAD, although the mechanisms mediating these relationships remain unclear. Compared to European Americans, African Americans (AAs) have higher rates of morbidity and mortality from CAD. Although depression is common in AAs, its role in the development and features of CAD in this group has not been well examined. This project hypothesizes that the relationships between depression and CAD can be explained by common physiological pathways and gene-environment interactions. Thus, the primary aims of this ongoing project are to: a) determine the prevalence of CAD and depression phenotypes in a population-based sample of community-dwelling older AAs; b) examine the relationships between CAD and depression phenotypes in this population; and c) evaluate genetic variants from serotoninP and inflammatory pathways to discover potential gene-depression interactions that contribute significantly to the presence of CAD in AAs.

Methods/design: The St. Louis African American Health (AAH) cohort is a population-based panel study of community-dwelling AAs born in 1936-1950 (inclusive) who have been followed from 2000/2001 through 2010. The AAH-Heart study group is a subset of AAH participants recruited in 2009-11 to examine the inter-relationships between depression and CAD in this population. State-of-the-art CAD phenotyping is based on cardiovascular characterizations (coronary artery calcium, carotid intima-media thickness, cardiac structure and function, and autonomic function). Depression phenotyping is based on standardized questionnaires and detailed interviews. Single nucleotide polymorphisms of selected genes in inflammatory and serotonin-signaling pathways are being examined to provide information for investigating potential gene-depression interactions as modifiers of CAD traits. Information from the parent AAH study is being used to provide population-based prevalence estimates. Inflammatory and other biomarkers provide information about potential pathways.

(Continued on next page)
\end{abstract}

\footnotetext{
* Correspondence: vdavila@wustl.edu

${ }^{1}$ Cardiovascular Imaging and Clinical Research Core Laboratory, Cardiovascular Division, Washington University School of Medicine, 660 South Euclid

Avenue, Campus Box 8086, St. Louis, MO 63110, USA

Full list of author information is available at the end of the article
} 
(Continued from previous page)

Discussion: This population-based investigation will provide valuable information on the prevalence of both depression and CAD phenotypes in this population. The study will examine interactions between depression and genetic variants as modulators of CAD, with the intent of detecting mechanistic pathways linking these diseases to identify potential therapeutic targets. Analytic results will be reported as they become available.

Keywords: Coronary artery disease, Depression, Genetic analyses, African Americans, Inflammatory biomarkers, Inflammatory pathway, Serotonin-signaling pathway, Heart rate variability, Built environment, Bayesian analysis

\section{Background}

Coronary artery disease (CAD) is the leading cause of cardiovascular morbidity and mortality and one of the most prevalent chronic diseases in the industrialized world and in most developing countries [1]. Over 82 million Americans have at least one type of cardiovascular disease [2]. In 2008, CAD was responsible for one out of every six deaths in the Unites States, and each year 1.26 million Americans suffer a new or recurrent myocardial infarction [2]. Cardiac events are more prevalent in depressed patients with $C A D$, and patients with CAD have increased burden of depressive conditions.

Depression is a risk factor for incident CAD and for cardiac-related morbidity and mortality [3-17]. Depression is also highly prevalent in patients with CAD, At any time point, about $20 \%$ of patients with CAD are experiencing an episode of major depression, and a comparable proportion have minor depression; [18-23]. Studies have found that a history of major depression, $[3,4]$ depression symptoms, [5-12] clinical depression, [4,13-16] and an increase in depression symptoms over time [16,17] predict incidence of heart disease and death from cardiac causes. Depression is not only a risk factor for incident CAD, but also for cardiac mortality and morbidity in patients who have established heart disease. Depression doubles the risk for cardiac events, including cardiac mortality, in the 12 months following initial diagnostic coronary catheterization and angiography $[7,24]$. Depression is also is a risk factor for mortality and cardiac events in patients undergoing coronary artery bypass graft surgery, $[7,25,26]$ and following an acute coronary syndrome [27-41].

The INTERHEART study, comprised of 15,542 cases and 14,820 controls from 52 countries representing diverse world populations, identified 9 modifiable risk factors (smoking, diabetes, hypertension, abdominal obesity, fruits/vegetable intake, exercise, alcohol consumption, ApoB/ApoA1 ratio, and a psychosocial index) that account for $90 \%$ of the population attributable risk for myocardial infarction. The psychosocial index (a composite score reflective of depression, locus of control, perceived stress, and life events) was responsible for $32.5 \%$ of the population attributable risk for $\mathrm{CAD}$, which was greater than the risk associated with each of hypertension, diabetes, abdominal obesity, fruit/vegetable intake, and alcohol consumption $[42,43]$. While depression and CAD may be two common independent disorders, it is possible that common pathophysiological mechanisms underpin both diseases.

However, the precise molecular and genetic mechanisms that may underlie both diseases remain largely unknown. Plausible pathways through which depression may increase the risk of cardiac morbidity and mortality include interactions between genetic variants and depressive phenotype (representing the environment) [44-46]. There is extensive evidence that mood disorders are heritable $[47,48]$. For example, heritability has been estimated on the order of $40 \%$ for unipolar depression [49]. The strongest familial risk is found in patients with recurrent major depression [50,51]. There is also evidence that cardiac risk factors and ischemic heart disease are heritable [52-55]. Recent studies have considered whether shared genetic factors help explain the relationship between depression and CAD. A variance component analysis of 2,731 male-male twin pairs from the Vietnam Era Twin Registry (mean age $42 \pm 3$ years) showed that shared genetic risk factors may underlie this relationship, as significant genetic correlations between depression and hypertension $(r=.19)$ and between depression and CAD $(r=.42)$ were found [44]. Importantly, statistical models have shown that CAD shares at least as much genetic variance with depression as it does with hypertension [56].

Inflammatory and serotonin-signaling pathways have been identified as risk factors for both CAD and depression. There is ample evidence to support a critical role for proinflammatory cytokines in the development of CAD, and inflammatory biomarkers have been associated with a variety of CAD-related traits $[57,58]$. The most studied of these biomarkers is the acute phase reactant C-reactive protein (CRP), which has been shown to be independently associated with the presence of carotid plaque [59] and increased carotid intima-media thickness; [60] it is also predictive of future CAD events [61-66]. Increases in inflammatory biomarkers have also been associated with depression, $[67,68]$ and inflammation has been postulated to mediate the association between depression and CAD [69]. Serotonin, which is secreted by activated platelets, promotes thrombogenesis, mitogenesis, and proliferation of smooth muscle cells and has been shown to be associated 
with CAD and occurrence of cardiac events, even after adjustment for conventional risk factors [70]. Furthermore, diminished heart rate variability, a biomarker representing disordered autonomic function associated with cardiovascular mortality, has been identified in depression and anxiety. Treatment with serotonin-reuptake inhibitors may normalize heart rate variability in these patients [71]. Since inflammation and serotonin signaling pathways have been identified as risk factors for CAD events and associated with depression, it has been postulated that genetic variants in these pathways may mediate the association between depression and CAD [72].

African Americans (AAs) have traditionally been an understudied group in all aspects of biomedical and behavioral research; this is particularly true with depression, and more so in studies investigating the genetic underpinnings of depression. Nationally, AAs have higher rates of morbidity and mortality from CAD than European Americans; [73] notably, rates of death from heart disease are 1.2 times higher among AAs in the City of St. Louis compared with the national average [74]. Limited data suggest that the prevalence of major depressive disorder is at least as high in AAs as in European Americans [75,76]. Despite its importance, we are unaware of any studies examining shared biological pathways and genetic explanations for the depression-CAD relationship in AAs.

The St. Louis African American Health (AAH) cohort is a population-based cohort study of community-dwelling AAs born in 1936-1950 (inclusive). The AAH-Heart study group is a subset of AAH participants who were recruited in 2009-11 to examine the inter-relationships between depression and CAD in this population and examine potential biological pathways and genetic underpinnings that could explain the identified relationships. This publication describes the structure and content of the project. Analytic results will be reported as they become available.

\section{Methods/design Objectives}

The primary objectives of AAH-Heart are three-fold: First, to identify the prevalence of CAD and depression in a population-based sample of community-dwelling AAs aged 59-75 years-old. Second, to examine the relationships between $\mathrm{CAD}$ and depression. Third, to evaluate interactions between depression and variants in serotonin-signaling and inflammatory pathway genes (representing geneenvironment interactions) potentially to identify underlying physiological mechanisms that help explain the identified relationships between depression and CAD. Phenotypes for both CAD and depression will be defined using clinically relevant definitions based on state-of-the-art methods for characterizing these phenotypes. We will also investigate multiple biomarkers as potential mediators of previously identified depression-CAD-gene relationships.

\section{Study design}

\section{Study population}

Study participants were recruited from the parent African American Health (AAH) project, a well-characterized cohort of 998 community-dwelling AAs representing the AA population in two diverse geographic and socioeconomic areas of St. Louis, MO. Participants were self-declared African American or black, born between 1936 and 1950 (inclusive; aged 49-65 at their baseline evaluation in 2000-2001), with an initial recruitment rate of $76 \%$. They were followed through 2010 (9 years), and wave-to-wave retention was $95 \%$ among surviving participants. AAH recruitment and sampling procedures have been previously described [77]. The AAH cohort underwent 7 waves of assessments ( 3 in-home and 4 by telephone) that included characterization of important life course factors (e.g., reported weight; self-reported physical activity; physical, cognitive, and psychosocial functioning; comorbid diseases; socioeconomic status; and health-related quality of life). Importantly, sampling weights supplied by the contract survey organization combined with propensity score re-weighting adjustments for differential involvement in AAH-Heart permit the AAH-Heart results to represent population-based estimates of the noninstitutionalized AA population in the original parent study areas as of the 2000 Census [78].

\section{Enrollment}

From 2009-2011, 735 AAH participants, representing the remaining AAH members available in 2009, were contacted via mail and/or telephone and asked to participate in the AAH-Heart study. Of these, 430 (58.1\%) were not enrolled to the AAH-Heart ancillary study for the following reasons: declined participation $(\mathrm{n}=152)$, failure to contact (e.g., multiple attempts, disconnected or wrong telephone numbers; $n=246$ ), relocation outside the St. Louis metropolitan area, institutionalized, or incarcerated $(n=26)$, or death since 2009 (6). A total of 305 (41.5\%) of the potential 735 AAH participants were enrolled in the AAH-Heart study (Figure 1).

\section{Ethical approval}

The study is a joint effort of three academic institutions. The protocol was approved in full by the ethics committee at Washington University School of Medicine, and parts related to involvement of their institution were approved by the ethics committees of Saint Louis and Indiana Universities. Written informed consent was obtained from all AAH-Heart participants.

\section{Data collection}

Data for AAH-Heart were collected from June 2009 to November 2011. All tests, questionnaires, and interviews were administered by trained personnel using standardized 


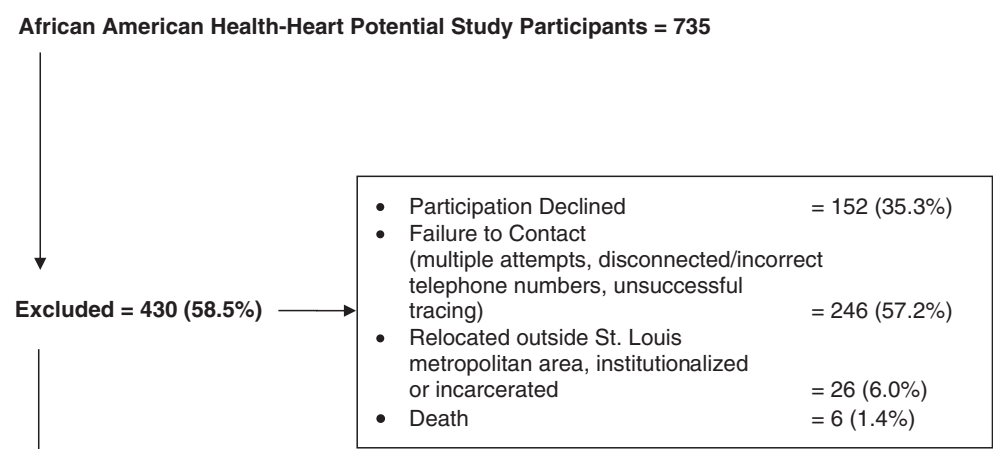

methods and interpreted by staff directly supervised by the investigators. Table 1 provides an overview of the variables and measurement details.

\section{Cardiovascular risks and characteristics}

A Medical History. Participants' general health status was characterized using the Charlton Comorbidity Index $[79,80]$. This instrument collects data regarding cardiovascular, neurologic/cerebrovascular, connective tissue, gastrointestinal, malignant, and pulmonary diseases. Data on medications and other health-related supplements were also collected by review of a self-reported medication list and/or examination of medication bottles.

B Cardiovascular health and behavior questionnaires. Six questions were obtained to determine consumption of certain fruit and vegetables [81]. Participants were also questioned regarding current and past tobacco use. The nine-item International Physical Activity Questionnaire-Short Form was administered to characterize the duration and intensity of physical activity [82].

C Anthropometric and hemodynamic measurements. Participants' weight, height, and waist/hip circumferences were measured. Three blood pressures were obtained in each arm after five minutes of rest in the seated position and averaged. The heart rate was obtained from a 12-lead electrocardiogram.

D Ankle-Brachial Index (ABI). ABI was obtained by measuring the blood pressures in the brachial arteries and in the posterior tibial and dorsalis pedis arteries using a hand-held Doppler probe using standard techniques.
E Six-minute walk distance test. For this self-paced, submaximal exercise test, individuals were asked to walk without physical assistance as fast as they could during a six-minute timed period [83].

F Coronary artery calcification. Participants were examined using a 64-slice dual-source multi-detector computerized tomography (MDCT) scanner (Somatom Sensation 64, Siemens, Forchheim, Germany) for characterization of coronary, carotid, and thoracic aorta calcification. Scan parameters included $24 \times 1.2 \mathrm{~mm}$ collimation, $1.5 \mathrm{~mm}$ slice thickness, $0.37 \mathrm{sec}$ rotation time, spiral mode, 120 kVp, 80 mAs. Cardiac-pulsing imaging reduced radiation exposure and cardiac motion. The scan was acquired during a single breath-hold at suspended end-expiration ( 5-15 sec duration). MDCT images were transferred to a workstation equipped for analysis. Intra- and inter-reader intraclass correlation coefficients for coronary calcium scores/volumes in our laboratory were $\geq 0.82$ and $\geq 0.97$, respectively.

G Echocardiography. M-Mode, two-dimensional, and Doppler echocardiographic measurements were performed for assessment of left ventricular (LV) structure and function. LV ejection fraction was calculated by the two-dimensional-derived method of discs. LV mass (LVM) was determined by the $\mathrm{M}$-mode-derived cubed method and indexed to height $^{2.7}\left(\mathrm{LVM} / \mathrm{Ht}^{2.7}\right)$. The presence of left ventricular hypertrophy is defined as an $\mathrm{LVM} / \mathrm{Ht}^{2.7}$ greater than two standard deviations above the mean (i.e. $>51 \mathrm{~g} / \mathrm{m}^{2.7}$ for men, $>49.5 \mathrm{~g} / \mathrm{m}^{2.7}$ for women) [84]. LV diastolic function was characterized as follows: 1) pulse-wave Doppler-derived transmitral indices recorded from the four-chamber view at the mitral 
Table 1 Variables and instruments

\begin{tabular}{ll}
\hline $\begin{array}{l}\text { Variables } \\
\text { Cardiovascular }\end{array}$ & Instruments \\
\hline Coronary, carotid, and thoracic aorta calcium scores & 64 -slice dual-source MDCT scanner \\
CIMT and carotid plaque burden & Bilateral carotid artery ultrasound imaging (mm) \\
ECG-derived - time domain analysis, frequency domain analysis, & 24-hour Holter monitor \\
heart rate turbulence & \\
LV structure, LV systolic/diastolic function, valve function & Echocardiography \\
Heart rate & Echocardiogram \\
Aortic compliance- pulse wave analysis, pulse wave velocity & SphygmoCor (AtCor Medical, Sydney, Australia) \\
Cardiovascular history & Charleston comorbidity Index (17 items) \\
Blood pressure & 3 times right and left arms \\
Ankle brachial index & Pocket fetal doppler Sonoline B \\
6-minute walk test & (Clinical Guard, Atlanta, GA)
\end{tabular}

\title{
Emotional status
}

DSM IV diagnosis: current and lifetime major unipolar depression, generalized anxiety and panic disorder

DISH (38 items)

Hamilton rating scale: severity of current depression

Psychiatric history

Screen for all exclusionary psychiatric conditions

Stressful/traumatic life events

LEC (1-15 events)

Depression

CES-D (11 items; $\geq 9$ points indicates clinically-relevant number of depressive symptoms)

\section{Current clinical covariates}

Fruit and vegetable consumption

CDC questionnaire (6 items)

Medication use

Self-report

Tobacco and alcohol use

Self-report

Anthropometrics- height, weight, waist/hip

Trained research members

Physical activity

IPAQ-short (9 items)

\section{Laboratory \& biomarker assays}

$\mathrm{BMP}$, fasting glucose, fasting lipid profile, and $\mathrm{HgbA}_{1 \mathrm{C}}$

Fasting blood draw

CRP, TNF-a, TNFR1, TNFR2, IL-6, TGF- $\beta$, VCAM, ICAM, MMP-9

Panomics multiplex immunoassay

(Affymetrix, Santa Clara, CA)

\section{Built environment}

Neighborhood of residence location

Questionnaire re: location; geographic information system analyses and in-person assessments as part of parent AAH study (2010)

\begin{abstract}
Abbreviations: BMP basic metabolic panel, CDC centers for disease control and prevention, CES-D center for epidemiologic studies depression scale, CIMT carotid intima-media thickness, CRP c-reactive protein, DISH depression interview and structured hamilton, DSM IV diagnostic and statistical manual of mental disorders fourth edition, EKG electrocardiogram, HbgA $A_{1 C}$ hemoglobin $A_{1 C}$, ICAM intercellular adhesion molecule, IL-6 Interleukin-6, IPAQ-Short international physical activity questionnaires-short form, LEC life events checklist, LV left ventricle, MDCT multi-detector computerized tomography, MMP-9 matrix metalloproteinase-9, TGF- $\beta$ transforming growth factor-beta, TNF- $a$, tumor necrosis factor-alpha, TNFR1 tumor necrosis factor receptor 1, TNFR2 denotes tumor necrosis factor receptor 2, VCAM vascular cell adhesion molecule.
\end{abstract}

valve leaflet tips, including the early diastolic (E-wave) and atrial (A-wave) velocities, E/A velocity ratio, E-wave deceleration time, and the isovolumic relaxation time; [85] 2) tissue Doppler imaging-derived early diastolic mitral annular velocity (E') obtained at the septal and lateral mitral annulus from the apical four-chamber view, and averaged [85-88]. Measurements were reported as the average of three consecutive cardiac cycles, interpreted by an experience sonographer. The intraclass correlation coefficients for echocardiographic indices measured at our laboratory range from $0.75-0.88$ for LV structure (i.e., LVM, LV end-diastolic and end-systolic 
volumes, left atrial diameter) and 0.88-0.96 for tissue Doppler imaging-derived indices of LV diastolic function (i.e., E' at the septal and lateral annulus).

$\mathrm{H}$ Carotid artery ultrasound for measurement of carotid intima-media thickness (CIMT). Bilateral carotid artery ultrasound imaging was performed using a 9-MHz linear array transducer of the extracranial carotid artery at the common carotid, approximately $1 \mathrm{~cm}$ proximal to the carotid bifurcation, using methods previously described [89]. Atherosclerotic plaque was defined as a focal intima-media thickness $>1.5 \mathrm{~mm}$ or focal wall thickening that protruded into the lumen $>0.5 \mathrm{~mm}$ or $>50 \%$ of the surrounding CIMT.

I 24-hour Holter monitor. Holter monitor recordings were analyzed using a CardioScan PC-based Holter analyzer, using standard research Holter analysis techniques to create an annotated beat-to-beat interbeat intervals file. Interbeat interval files were transferred to a Sun 450 computer for detailed heart rate variability (HRV) analysis using validated research software. Abnormal HRV, either markedly decreased or markedly erratic beat-to-beat changes in heart rate, is a marker for abnormal cardiac autonomic function [90]. HRV parameters included time domain measures, which are moment statistics of the amount of HRV on different scales and reflect the amount of autonomic modulation of heart rate. Detailed information on cardiac autonomic function at different underlying frequencies was obtained using frequency domain analysis of HRV. Non-linear HRV measures that assess the underlying pattern (totally random at one extreme and totally correlated at the other) were also calculated, as was heart rate turbulence (a measure of autonomic function derived from the heart rate response to ventricular premature beats, apparently reflecting baroreflex function [91-93]). Among predominantly white community-dwelling older adults in the Cardiovascular Health Study (CHS), both more abnormal non-linear HRV measures and abnormal heart rate turbulence have been associated with a high risk for cardiovascular mortality independent of traditional risk factors [94]. Also in CHS, depression has been associated with both more mortality and with non-linear HRV [95].

J Characterization of vascular compliance. Central aortic compliance was characterized by measurement of the pulse wave velocity (PWV) and augmentation index using the SphygmoCor ${ }^{\text {rm }}$ system (AtCor, Sydney, Australia) equipped with a single high-fidelity applanation tonometer probe. For the PWV, pressures were recorded from the carotid then femoral arteries; the transit time was calculated by registration with a simultaneously recorded electrocardiogram, using methods previously described $[96,97]$.

\section{Depression and psychosocial history}

A Depression Interview: A structured interview, the Depression Interview and Structured Hamilton (DISH), was used to diagnose current and lifetime major unipolar depression according to Diagnostic and Statistical Manual of Mental Disorders, Fourth Edition (DSM-IV) criteria; the presence and severity of current depression was determined from an embedded Hamilton Rating Scale for Depression, 17-item (HAM-D-17) [98]. The DISH also identifies depression subtypes (e.g., melancholic or atypical depression) and comorbid anxiety disorders, including generalized anxiety and panic disorder. Family history for psychiatric disorders was identified, as well as psychiatric conditions which are exclusions for this study (e.g., bipolar disorder, schizophrenia).

B Depression Self Report Inventory. The 11-item Center for Epidemiologic Studies Depression (CESD) Scale was administered to assess the presence and severity of depressive symptoms. A score of $\geq 9$ was used to define clinically significant depressive symptoms [99].

C The Life Events Checklist captured recent and past exposures to stressful life events [100].

\section{Built environment}

Each participant provided a detailed history of moves by providing the dates (month/year) and location (street number and name) of residences occupied since 2000. Additional questions probed reasons for relocations. This information will be used to determine the effects of the built environment and/or neighborhood conditions (such as nearby restaurants, grocery stores, green space, and yard and sidewalk quality) on cardiovascular and emotional health using geographic information system methods plus observational data from the parent study $[78,101,102]$.

\section{Laboratory assays}

Blood was obtained by venipuncture at the time of examination. A basic metabolic profile (glucose, calcium, sodium, potassium, chloride, bicarbonate, blood urea nitrogen, and creatinine), lipid profile (low-density lipoprotein cholesterol, high-density lipoprotein cholesterol, triglyceride, and total cholesterol), and $\mathrm{HgbA}_{1 \mathrm{C}}$ were obtained after an overnight fast on the day of enrollment. After blood extraction and processing, serum and plasma were stored in $1 \mathrm{~mL}$ aliquots in $\mathrm{O}$-ring tubes at $-80^{\circ} \mathrm{C}$ 
pending further analysis for fasting insulin, leptin, and inflammatory biomarkers. Inflammatory biomarkers included CRP, tumor necrosis factor-alpha (TNF- $\alpha$ ), tumor necrosis factor-receptor 1 (TNFR1), tumor necrosis factor receptor 2 (TNFR2), interleukin-6 (IL-6), transforming growth factor-beta (TGF- $\beta$ ), vascular cell adhesion molecule (VCAM), intercellular adhesion molecule (ICAM), and matrix metalloproteinase-9 (MMP-9), which were assayed from serum using the Panomics multiplex immunoassay magnetic bead assay kit (Affymetrix, Santa Clara, CA).

\section{Genetic studies}

Whole blood was collected in EDTA-treated vacuum containers and then frozen at $-80^{\circ} \mathrm{C}$ until DNA extraction using QIAGEN Autopure LS Large Nucleic Acid Purification Instrument (Gentra Systems, Minneapolis, MN). Extracted DNA was stored at $-80 \mathrm{C}$ pending genotyping (in process). Genotyping is being performed using a commercially available platform at the Washington University Genome Technology Access Center. Single nucleotide polymorphisms are being selected from among inflammatory and serotonin signaling pathway genes with the goal to maximize the information content and to test variants previously implicated in cardiovascular and/or psychiatric disorders. When referent genetic sequences and/or variant data are accessed, information from African and AfricanAmerican populations will be prioritized.

\section{Statistical analyses}

Initial data processing and screening will be carried out by established procedures for data quality control and generation of derived variables (e.g., univariate analysis of individual phenotypes and identifying outliers). Versioncontrolled analytic datasets will be made and distributed to all approved study investigators for downstream analyses. Latent factor analysis will be performed on panels of observed cardiovascular findings to extract underlying patterns of data (i.e., "traits") more proximally associated with CAD [103]. The latent factors will first be extracted from panels of variables representing cardiovascular attributes, and then again from panels combining both cardiovascular and depressive characteristics. By comparing results of analyses using CAD-only versus CAD + depression latent traits, subtypes of CAD potentially affected by gene-depression interactions will be identified. Simple associations between CAD/depression traits and individual genetic variants will be tested by linear or logistic regression. A modified generalized linear model accounting for gene-gene and gene-depression interactions (using both observed characteristics and extracted latent traits) will be performed to test modifying effects of depression on CAD phenotypes. Exploratory Bayesian network analyses will be performed to obtain an overview of interactions among the many factors (genetic and non-genetic) important to
CAD [104,105]. Additional secondary analyses will explore whether the association between depression and CAD are mediated through LV structure/function, [106] autonomic dysfunction (e.g., HRV), [71] inflammatory biomarkers, [69] the built environment, [78] and/or health behaviors (e.g., diet, exercise, tobacco, medication use, etc.) [107]. The overarching hypothesis is that genes related to the serotonin signaling, inflammatory processes, and/or autonomic function will help explain the relationships between the depression phenotype and CAD-related phenotypes.

\section{Discussion}

This study was designed to evaluate the contributions from depression to manifestations of CAD through common gene-gene and/or gene-environment interactions via the primary and secondary study objectives described above. This is an important and innovative study in several respects. First, the mechanisms contributing to CAD in AAs are poorly understood. For example, although AAs experience more morbidity and mortality from CAD than do European Americans, they have less obstructive CAD than do European Americans [73]. Second, this study uses state-of-the-art non-invasive cardiac imaging techniques to allow exquisite characterization of coronary artery calcium, CIMT, and left ventricular structure and systolic/diastolic function to evaluate manifestations of CAD. Likewise, for the evaluation of depression phenotype, detailed, validated psychiatric interviews and questionnaires were used. Third, by focusing the analyses on continuous cardiovascular phenotypes, including both raw (e.g., coronary artery calcium volume) and extracted latent traits, the power to detect significant associations will be greater than comparable analyses of dichotomized CAD traits (e.g., history of myocardial infarction). Fourth, the proposed genetic investigations are designed to take advantage of well-established genetic analytic tools supplemented by novel analytic methods developed and validated by the investigative team [103]. Fifth, multiple biomarkers and other clinical data permit the examination of physiological pathways by which depression affects CAD outcomes.

There is compelling evidence that autonomic dysregulation is one of the mechanisms by which depression contributes to CAD [108]. Studies of depressed, medically-well psychiatric patients have reported elevated levels of plasma and urinary catecholamines (primarily norepinephrine) compared to controls [109-115]. Studies have reported higher heart rates and lower HRV in depressed patients than in non-depressed controls, [111,113-120] consistent with altered cardiac autonomic nervous system function [90]. Abnormal HRV has been described as resulting from an imbalance between the sympathetic and parasympathetic regulatory control of the heartbeat [121] and/or the lack of an integrated regulation of the heartbeat [122]. (Notably, low HRV also has predicted mortality in patients 
with a recent myocardial infarction [123-126] and with stable coronary disease [127] and abnormal heart rate turbulence has been found to be a strong predictor of mortality after acute myocardial infarction as well [128-130]).

Biologic factors shared by both CAD and depression suggest possible common genetic pathways, such as inflammatory and/or serotonin-signaling pathways that appear to underlie both diseases. Evidence of genetic pleiotropy does not eliminate or fully explain other potential causal relationships, including pathways by which certain gene-environment interactions may cause depression and depression may in turn accelerate the development, progression, and/or morbidity associated with CAD [131]. For example, Nakatani et al. studied the "short" (S) allele of the serotonin transporter gene-linked polymorphic region (SLC6A4 5-HTTLPR, minor allele frequency 20\%) in 2,509 Japanese post-myocardial infarction patients [132]. Depression was significantly more common among patients with (48\%) than without (35\%) the S allele. The S allele predicted an increased risk of cardiac events (hazards ratio $=1.69$ ), but its effect was reduced to non-significance by adjustment for depressive symptoms, suggesting that depression may mediate the effect of this polymorphism on cardiac outcomes.

Elevated inflammatory biomarkers, particularly CRP, IL-6, and TNF- $\alpha$, also have been found in medically healthy adults with depression, and in depressed patients with CAD [133-139]. These inflammatory molecules are risk markers for cardiac morbidity and mortality $[57,58,63,65,66]$. Thus, markers of proinflammatory and serotonin signaling pathways that have been identified as risk factors for CAD and cardiac events have also been found to be elevated in depressed patients with CAD. For this reason, genes involved in inflammatory and serotonin-signaling pathways have recently been identified as candidates for elucidating the mechanisms causing the association between depression and CAD [72].

\section{Limitations}

Although the parent AAH project is a longitudinal study, the AAH-Heart ancillary study is cross-sectional, and thus causality cannot be determined. Second, although we can estimate effects at the population level via the original sample weights plus re-weighting adjustments based on propensity scores for inclusion in AAH-Heart, this approach is somewhat less precise than estimates based on a freshly-drawn population-based sample, albeit a great deal less expensive than the latter method. Third, although we examine a large number of biomarkers and clinical data, it is impossible to include every potential mediating, moderating, and/or confounding factor. Fourth, power predictably will be adequate for many of the planned analysis but marginal or low for others, depending on numerous issues involved in the specific analytic approach being pursued.

\section{Summary}

AAH-Heart provides an unparalleled opportunity to study CAD-depression-gene relationships in a particularly vulnerable population, i.e., AAs entering their senior years. The investigations are designed to elucidate important pathophysiological relationships and pathways to facilitate identification of appropriate targets for clinical interventions to modify the adverse bidirectional relationships between depression and CAD, not only in AA populations but conceivably in other populations as well.

\begin{abstract}
Abbreviations
AAs: African Americans; AAH: African American Health; AAH-Heart: African American health-heart; ABl: Ankle-brachial index; BMP: Basic metabolic panel; CIMT: Carotid intima media thickness; CES-D: Center for epidemiologic studies depression, 11-item scale; CAD: Coronary artery disease; CRP: C-reactive protein; DISH: Depression interview and structured Hamilton; DSM-IV: Diagnostic and statistical manual of mental disorders, fourth edition; ECG: Electrocardiogram; HRV: Heart rate variability; ICAM: Intercellular adhesion molecule; IL-6: Interleukin6; LV: Left ventricular; MMP-9: Matrix metalloproteinase-9; MDCT: Multi-detector computed tomography; A-wave: Peak atrial late diastolic velocity; E-wave: Peak early-diastolic transmitral velocity; PW: Pulse wave velocity; TGF- $\beta$ : Transforming growth factor-beta; TNF-a: Tumor necrosis factor-alpha; TNFR1: Tumor necrosis factor-receptor 1; TNFR2: Tumor necrosis factor receptor 2; VCAM: Vascular cell adhesion molecule.
\end{abstract}

\section{Competing interests}

The authors declare that they have no competing interests related to this work.

\section{Authors' contributors}

LdIF, RMC, CCG, MS, PS, DKM, and VGD-R participated in the study conception, design, and grant writing; acquisition, analysis and interpretation of data. RRB, LdIF, JLR, TKM, and TEB participated in participant recruitment, data management, and data analysis/interpretation. MS participated in data acquisition, management, analysis, and interpretation of built environment measures. $A B$ participated in data analysis/interpretation of MDCT images. CB-M and AER participated in analysis and interpretation of the biomarker data. All authors participated in the writing of the manuscript and provided important intellectual content. In addition, all authors read and approved the final manuscript

\section{Acknowledgements}

This study originated as an $\mathrm{NIH}$ Revision to the Physical Frailty in Urban African Americans (PFUAAA) project and was supported by grants NIA AG010436 (PFUAA) and NHLBI HL094668. The funding agencies played no role design or conduct of the study; data collection or interpretation; manuscript preparation; or decision to submit for publication. The opinions expressed here are those of the authors and do not necessarily reflect those of the funding agencies or the involved academic institutions.

\section{Author details}

${ }^{1}$ Cardiovascular Imaging and Clinical Research Core Laboratory, Cardiovascular Division, Washington University School of Medicine, 660 South Euclid Avenue, Campus Box 8086, St. Louis, MO 63110, USA. ${ }^{2}$ Department of Psychiatry, Washington University School of Medicine, 4320 Forest Park Avenue Suite 301, St. Louis, MO 63108, USA. ${ }^{3}$ Endocrinology, Metabolism and Lipid Research Division, Washington University School of Medicine, 660 South Euclid Avenue, St. Louis, MO 63110, USA. ${ }^{4}$ Division of Biostatistics, Washington University School of Medicine, 660 South Euclid Avenue, Campus Box 8067, St. Louis, MO 63110, USA. ${ }^{5}$ Mallinckrodt Institute of Radiology, Washington University School of Medicine, 660 South Euclid Avenue, St. Louis, MO 63110, USA. ${ }^{6}$ Division of Health Behavior Research, Washington University School of Medicine, 660 south Euclid Avenue, St. Louis, MO 63110, USA. ${ }^{7}$ Department of Neurology \& Psychiatry, School of Medicine, Saint Louis University, St. Louis, MO, USA. ${ }^{8}$ Center for Outcomes Research, Saint Louis University, 3545 Lafayette Avenue, St. Louis, MO 63104, USA. ${ }^{9}$ Regenstrief Institute, Inc., and Indiana University Center for Aging Research, School of Medicine, Indiana University, 410 West 10th Street, Indianapolis, IN 46202, USA. 
Received: 24 May 2013 Accepted: 13 August 2013

Published: 8 September 2013

\section{References}

1. Gaziano TA: Cardiovascular disease in the developing world and its cost-effective management. Circulation 2005, 112:3547-3553.

2. Roger VL, Go AS, Lloyd-Jones DM, Benjamin EJ, Berry JD, Borden WB, Bravata DM, Dai S, Ford ES, Fox CS, Fullerton HJ, Gillespie C, Hailpern SM, Heit JA, Howard VJ, Kissela BM, Kittner SJ, Lackland DT, Lichtman JH, Lisabeth LD, Makuc DM, Marcus GM, Marelli A, Matchar DB, Moy CS, Mozaffarian D, Mussolino ME, Nichol G, Paynter NP, Soliman EZ, et al: Heart disease and stroke statistics-2012 update: a report from the American heart association. Circulation 2012, 125:e2-e220.

3. Cohen HW, Madhavan S, Alderman MH: History of treatment for depression: risk factor for myocardial infarction in hypertensive patients. Psychosom Med 2001, 63:203-209.

4. Pratt LA, Ford DE, Crum RM, Armenian HK, Gallo JJ, Eaton WW: Depression, psychotropic medication, and risk of myocardial infarction, prospective data from the Baltimore ECA follow-up. Circulation 1996, 94:3123-3129.

5. Anda R, Williamson D, Jones D, Macera C, Eaker E, Glassman A, Marks J: Depressed affect, hopelessness, and the risk of ischemic heart disease in a cohort of U.S. adults. Epidemiology 1993, 4:285-294.

6. Ariyo AA, Haan M, Tangen CM, Rutledge JC, Cushman M, Dobs A, Furberg $\mathrm{CD}$ : Depressive symptoms and risks of coronary heart disease and mortality in elderly americans, cardiovascular health study collaborative research group. Circulation 2000, 102:1773-1779.

7. Barefoot JC, Helms MJ, Mark DB, Blumenthal JA, Califf RM, Haney TL, O'Connor CM, Siegler IC, Williams RB: Depression and long-term mortality risk in patients with coronary artery disease. Am J Cardiol 1996, 78:613-617.

8. Ferketich AK, Schwartzbaum JA, Frid DJ, Moeschberger ML: Depression as an antecedent to heart disease among women and men in the NHANES I study. National health and nutrition examination survey. Arch Intern Med 2000, 160:1261-1268.

9. De Leon CF M, Krumholz HM, Seeman TS, Vaccarino V, Williams CS, Kasl SV, Berkman LF: Depression and risk of coronary heart disease in elderly men and women: New haven EPESE, 1982-1991. Established populations for the epidemiologic studies of the elderly. Arch Intern Med 1998, 158:2341-2348.

10. Sesso HD, Kawachi I, Vokonas PS, Sparrow D: Depression and the risk of coronary heart disease in the normative aging study. Am J Cardiol 1998, 82:851-856.

11. Simonsick EM, Wallace RB, Blazer DG, Berkman LF: Depressive symptomatology and hypertension-associated morbidity and mortality in older adults. Psychosom Med 1995, 57:427-435.

12. Whooley MA, Browner WS: Association between depressive symptoms and mortality in older women. Study of osteoporotic fractures research group. Arch Intern Med 1998, 158:2129-2135.

13. Aromaa A, Raitasalo $R$, Reunanen A, Impivaara O, Heliovaara M, Knekt $P$, Lehtinen $\mathrm{V}$, Joukamaa M, Maatela J: Depression and cardiovascular diseases. Acta Psychiatr Scand Suppl 1994, 377:77-82.

14. Ford DE, Mead LA, Chang PP, Cooper-Patrick L, Wang NY, Klag MJ: Depression is a risk factor for coronary artery disease in men: the precursors study. Arch Intern Med 1998, 158:1422-1426.

15. Hippisley-Cox J, Fielding K, Pringle M: Depression as a risk factor for ischaemic heart disease in men: population based case-control study. BMJ 1998, 316:1714-1719.

16. Penninx BW, Guralnik JM, De Leon CF M, Pahor M, Visser M, Corti MC, Wallace RB: Cardiovascular events and mortality in newly and chronically depressed persons > 70 years of age. Am J Cardiol 1998, 81:988-994.

17. Wassertheil-Smoller S, Applegate WB, Berge K, Chang CJ, Davis BR, Grimm R Jr, Kostis J, Pressel S, Schron E: Change in depression as a precursor of cardiovascular events. SHEP cooperative research group (systoloc hypertension in the elderly). Arch Intern Med 1996, 156:553-561.

18. Carney RM, Rich MW, Tevelde A, Saini J, Clark K, Jaffe AS: Major depressive disorder in coronary artery disease. Am J Cardiol 1987, 60:1273-1275.

19. Carney RM, Freedland KE, Jaffe AS: Insomnia and depression prior to myocardial infarction. Psychosom Med 1990, 52:603-609.

20. Forrester AW, Lipsey JR, Teitelbaum ML, DePaulo JR, Andrzejewski PL: Depression following myocardial infarction. Int J Psychiatry Med 1992, 22:33-46.

21. Gonzalez MB, Snyderman TB, Colket JT, Arias RM, Jiang JW, O'Connor CM, Krishnan KR: Depression in patients with coronary artery disease. Depression 1996, 4:57-62.
22. Hance M, Carney RM, Freedland KE, Skala J: Depression in patients with coronary heart disease. A 12-month follow-up. Gen Hosp Psychiatry $1996,18: 61-65$

23. Schleifer SJ, Macari-Hinson MM, Coyle DA, Slater WR, Kahn M, Gorlin R, Zucker HD: The nature and course of depression following myocardial infarction. Arch Intern Med 1989, 149:1785-1789.

24. Carney RM, Rich MW, Freedland KE, Saini J, TeVelde A, Simeone C, Clark K: Major depressive disorder predicts cardiac events in patients with coronary artery disease. Psychosom Med 1988, 50:627-633.

25. Blumenthal JA, Lett HS, Babyak MA, White W, Smith PK, Mark DB, Jones R, Mathew JP, Newman MF: Depression as a risk factor for mortality after coronary artery bypass surgery. Lancet 2003, 362:604-609.

26. Connerney I, Shapiro PA, McLaughlin JS, Bagiella E, Sloan RP: Relation between depression after coronary artery bypass surgery and 12-month outcome: a prospective study. Lancet 2001, 358:1766-1771.

27. Ahern DK, Gorkin L, Anderson JL, Tierney C, Hallstrom A, Ewart C, Capone RJ, Schron E, Kornfeld D, Herd JA, et al: Biobehavioral variables and mortality or cardiac arrest in the cardiac arrhythmia pilot study (CAPS). Am J Cardiol 1990, 66:59-62.

28. Bush DE, Ziegelstein RC, Tayback M, Richter D, Stevens S, Zahalsky H, Fauerbach JA: Even minimal symptoms of depression increase mortality risk after acute myocardial infarction. Am J Cardiol 2001, 88:337-341.

29. Carney RM, Blumenthal JA, Catellier D, Freedland KE, Berkman LF, Watkins LL, Czajkowski SM, Hayano J, Jaffe AS: Depression as a risk factor for mortality after acute myocardial infarction. Am J Cardiol 2003, 92:1277-1281.

30. Carney RM, Freedland KE, Steinmeyer B, Blumenthal JA, Berkman LF, Watkins LL, Czajkowski SM, Burg MM, Jaffe AS: Depression and five year survival following acute myocardial infarction: a prospective study. $J$ Affect Disord 2008, 109:133-138

31. Denollet J, Sys SU, Brutsaert DL: Personality and mortality after myocardial infarction. Psychosom Med 1995, 57:582-591.

32. Drago S, Bergerone S, Anselmino M, Varalda PG, Cascio B, Palumbo L, Angelini G, Trevi PG: Depression in patients with acute myocardial infarction: influence on autonomic nervous system and prognostic role. Results of a five-year follow-up study. Int I Cardiol 2007, 115:46-51.

33. Frasure-Smith N, Lesperance F, Talajic M: Depression following myocardial infarction. Impact on 6-month survival. JAMA 1993, 270:1819-1825.

34. Frasure-Smith N, Lesperance F, Talajic M: Depression and 18-month prognosis after myocardial infarction. Circulation 1995, 91:999-1005.

35. Grace SL, Abbey SE, Kapral MK, Fang J, Nolan RP, Stewart DE: Effect of depression on five-year mortality after an acute coronary syndrome. Am J Cardiol 2005, 96:1179-1185.

36. Irvine J, Basinski A, Baker B, Jandciu S, Paquette M, Cairns J, Connolly S, Roberts R, Gent M, Dorian P: Depression and risk of sudden cardiac death after acute myocardial infarction: testing for the confounding effects of fatigue. Psychosom Med 1999, 61:729-737.

37. Kaufmann MW, Fitzgibbons JP, Sussman EJ, Reed JF 3rd, Einfalt JM, Rodgers JK, Fricchione GL: Relation between myocardial infarction, depression, hostility, and death. Am Heart J 1999, 138:549-554.

38. Ladwig KH, Kieser M, Konig J, Breithardt G, Borggrefe M: Affective disorders and survival after acute myocardial infarction. Results from the post-infarction late potential study. Eur Heart J 1991, 12:959-964.

39. Lesperance F, Frasure-Smith N, Talajic M: Major depression before and after myocardial infarction: its nature and consequences. Psychosom Med 1996, 58:99-110.

40. Lesperance F, Frasure-Smith N, Juneau M, Theroux P: Depression and 1-year prognosis in unstable angina. Arch Intern Med 2000, 160:1354-1360.

41. Parakh K, Thombs BD, Fauerbach JA, Bush DE, Ziegelstein RC: Effect of depression on late (8 years) mortality after myocardial infarction. Am J Cardiol 2008, 101:602-606.

42. Yusuf S, Hawken S, Ounpuu S, Dans T, Avezum A, Lanas F, McQueen M, Budaj A, Pais P, Varigos J, Lisheng L: INTERHEART study investigators: effect of potentially modifiable risk factors associated with myocardial infarction in 52 countries (the INTERHEART study): case-control study. Lancet 2004, 364:937-952.

43. Rosengren A, Hawken S, Ounpuu S, Sliwa K, Zubaid M, Almahmeed WA, Blackett KN, Sitthi-amorn C, Sato H, Yusuf S, Investigators I: Association of psychosocial risk factors with risk of acute myocardial infarction in 11119 cases and 13648 controls from 52 countries (the INTERHEART study): case-control study. Lancet 2004, 364:953-962. 
44. Scherrer JF, Xian H, Bucholz KK, Eisen SA, Lyons MJ, Goldberg J, Tsuang M, True WR: A twin study of depression symptoms, hypertension, and heart disease in middle-aged men. Psychosom Med 2003, 65:548-557.

45. Ni W, Watts SW: 5-Hydroxytryptamine in the cardiovascular system: focus on the serotonin transporter (SERT). Clin Exp Pharmacol Physiol 2006, 33:575-583.

46. Otte C, McCaffery J, Ali S, Whooley MA: Association of a serotonin transporter polymorphism (5-HTTLPR) with depression, perceived stress, and norepinephrine in patients with coronary disease: the heart and soul study. Am J Psychiatry 2007, 164:1379-1384.

47. Kendler KS, Neale MC, Kessler RC, Heath AC, Eaves L: A population-based twin study of major depression in women. The impact of varying definitions of illness. Arch Gen Psychiatry 1992, 49:257-266.

48. Lyons MJ, Eisen SA, Goldberg J, True W, Lin N, Meyer JM, Toomey R, Faraone SV, Merla-Ramos M, Tsuang MT: A registry-based twin study of depression in men. Arch Gen Psychiatry 1998, 55:468-472.

49. Tsuang MT, Faraone SV: The genetics of mood disorders. Baltimore: Johns Hopkins University Press; 1990.

50. Moldin SO, Reich T, Rice JP: Current perspectives on the genetics of unipolar depression. Behav Genet 1991, 21:211-242.

51. Sullivan PF, Neale MC, Kendler KS: Genetic epidemiology of major depression: review and meta-analysis. Am J Psychiatry 2000, 157:1552-1562.

52. Austin MA, King MC, Bawol RD, Hulley SB, Friedman GD: Risk factors for coronary heart disease in adult female twins. Genetic heritability and shared environmental influences. Am J Epidemiol 1987, 125:308-318.

53. Feinleib M, Garrison RJ, Fabsitz R, Christian JC, Hrubec Z, Borhani NO, Kannel WB, Rosenman R, Schwartz JT, Wagner JO: The NHLBI twin study of cardiovascular disease risk factors: methodology and summary of results. Am J Epidemiol 1977, 106:284-285.

54. Friedlander $Y$, Siscovick DS, Weinmann S, Austin MA, Psaty BM, Lemaitre RN, Arbogast $P$, Raghunathan TE, Cobb LA: Family history as a risk factor for primary cardiac arrest. Circulation 1998, 97:155-160.

55. Reed T, Quiroga J, Selby JV, Carmelli D, Christian JC, Fabsitz RR, Grim CE: Concordance of ischemic heart disease in the NHLBI twin study after 14-18 years of follow-up. J Clin Epidemiol 1991, 44:797-805.

56. Licinio J, Yildiz B, Wong ML: Depression and cardiovascular disease: cooccurrence or shared genetic substrates? Mol Psychiatry 2002, 7:1031-1032.

57. Ridker PM, Rifai N, Pfeffer M, Sacks F, Lepage S, Braunwald E: Elevation of tumor necrosis factor-alpha and increased risk of recurrent coronary events after myocardial infarction. Circulation 2000, 101:2149-2153.

58. Ridker PM, Rifai N, Stampfer MJ, Hennekens CH: Plasma concentration of interleukin- 6 and the risk of future myocardial infarction among apparently healthy men. Circulation 2000, 101:1767-1772.

59. Ahluwalia N, Drouet L, Ruidavets JB, Perret B, Amar J, Boccalon H, Hanaire-Broutin $\mathrm{H}$, Ferrieres J: Metabolic syndrome is associated with markers of subclinical atherosclerosis in a French population-based sample. Atherosclerosis 2006, 186:345-353.

60. Balletshofer BM, Haap M, Rittig K, Stock J, Lehn-Stefan A, Haring HU: Early carotid atherosclerosis in overweight non-diabetic individuals is associated with subclinical chronic inflammation independent of underlying insulin resistance. Horm Metab Res 2005, 37:331-335.

61. Corrado E, Rizzo M, Tantillo R, Muratori I, Bonura F, Vitale G, Novo S: Markers of inflammation and infection influence the outcome of patients with baseline asymptomatic carotid lesions: a 5-year follow-up study. Stroke 2006, 37:482-486.

62. Danesh J, Wheeler JG, Hirschfield GM, Eda S, Eiriksdottir G, Rumley A, Lowe GD, Pepys MB, Gudnason V: C-reactive protein and other circulating markers of inflammation in the prediction of coronary heart disease. N Engl J Med 2004, 350:1387-1397.

63. Danesh J, Collins R, Appleby P, Peto R: Association of fibrinogen, C-reactive protein, albumin, or leukocyte count with coronary heart disease: meta-analyses of prospective studies. JAMA 1998, 279:1477-1482.

64. Harris TB, Ferrucci L, Tracy RP, Corti MC, Wacholder S, Ettinger WH Jr, Heimovitz $\mathrm{H}$, Cohen HJ, Wallace R: Associations of elevated interleukin-6 and C-reactive protein levels with mortality in the elderly. Am J Med 1999, 106:506-512.

65. Ridker PM, Hennekens $\mathrm{CH}$, Buring JE, Rifai N: C-reactive protein and other markers of inflammation in the prediction of cardiovascular disease in women. N Engl J Med 2000, 342:836-843.

66. Ridker PM, Glynn RJ, Hennekens CH: C-reactive protein adds to the predictive value of total and $\mathrm{HDL}$ cholesterol in determining risk of first myocardial infarction. Circulation 1998, 97:2007-2011.
67. Howren MB, Lamkin DM, Suls J: Associations of depression with C-reactive protein, IL-1, and IL-6: a meta-analysis. Psychosom Med 2009, 71:171-186.

68. Miller AH, Maletic V, Raison CL: Inflammation and its discontents: the role of cytokines in the pathophysiology of major depression. Biol Psychiatry 2009, 65:732-741.

69. Stewart JC, Rand KL, Muldoon MF, Kamarck TW: A prospective evaluation of the directionality of the depression-inflammation relationship. Brain Behav Immun 2009, 23:936-944.

70. Vikenes K, Farstad M, Nordrehaug JE: Serotonin is associated with coronary artery disease and cardiac events. Circulation 1999, 100:483-489.

71. Gorman JM, Sloan RP: Heart rate variability in depressive and anxiety disorders. Am Heart J 2000, 140:77-83.

72. McCaffery JM, Frasure-Smith N, Dube MP, Theroux P, Rouleau GA, Duan Q, Lesperance F: Common genetic vulnerability to depressive symptoms and coronary artery disease: a review and development of candidate genes related to inflammation and serotonin. Psychosom Med 2006, 68:187-200.

73. Wyatt SB, Williams DR, Calvin R, Henderson FC, Walker ER, Winters K: Racism and cardiovascular disease in African Americans. Am J Med Sci 2003, 325:315-331.

74. Quesada LC: Public health: understanding Our needs, Update 2007. Saint Louis, MO: The City of Saint Louis Department of Health; 2007.

75. Weissman MM, Bruce ML, Leaf PJ, Florio LP, Holzer C: Affective disorders. In Psychiatric disorders in America. Edited by Robins LN, Reigier DA. New York: The Free Press; 1991:53-80.

76. Williams DR: Minority health in America. In Findings and policy implications from the commonwealth fund minority health survey. Edited by Hogue CJR, Hargraves MA, Collins KS. Baltimore, MD: Johns Hopkins University Press; 2000

77. Miller DK, Wolinsky FD, Malmstrom TK, Andresen EM, Miller JP: Inner city, middle-aged African Americans have excess frank and subclinical disability. J Gerontol A Biol Sci Med Sci 2005, 60:207-212.

78. Schootman $M$, Andresen EM, Wolinsky FD, Miller JP, Yan Y, Miller DK Neighborhood conditions, diabetes, and risk of lower-body functional limitations among middle-aged African Americans: a cohort study. BMC Publ Health 2010, 10:283.

79. Extermann M: Measuring comorbidity in older cancer patients. Eur J Cancer 2000, 36:453-471.

80. Extermann M: Measurement and impact of comorbidity in older cancer patients. Crit Rev Oncol Hematol 2000, 35:181-200.

81. Serdula M, Coates R, Byers T, Mokdad A, Jewell S, Chavez N, Mares-Perlman J, Newcomb P, Ritenbaugh C, Treiber F, et al: Evaluation of a brief telephone questionnaire to estimate fruit and vegetable consumption in diverse study populations. Epidemiology 1993, 4:455-463.

82. Ainsworth BE, Bassett DR Jr, Strath SJ, Swartz AM, O'Brien WL, Thompson RW, Jones DA, Macera CA, Kimsey CD: Comparison of three methods for measuring the time spent in physical activity. Med Sci Sports Exerc 2000, 32:\$457-\$464.

83. A. T. S. Committee on Proficiency Standards for Clinical Pulmonary Function Laboratories: ATS statement: guidelines for the six-minute walk test. Am J Respir Crit Care Med 2002, 166:111-117.

84. de Simone G, Daniels SR, Devereux RB, Meyer RA, Roman MJ, de Divitiis O, Alderman MH: Left ventricular mass and body size in normotensive children and adults: assessment of allometric relations and impact of overweight. J Am Coll Cardiol 1992, 20:1251-1260.

85. Quinones MA, Otto CM, Stoddard M, Waggoner A, Zoghbi WA, Doppler Quantification Task Force of the Nomenclature and Standards Committee of the American Society of Echocardiography: Recommendations for quantification of doppler echocardiography: a report from the doppler quantification task force of the nomenclature and standards committee of the American society of echocardiography. J Am Soc Echocardiogr 2002, 15:167-184.

86. Wang M, Yip GW, Wang AY, Zhang Y, Ho PY, Tse MK, Lam PK, Sanderson JE: Peak early diastolic mitral annulus velocity by tissue doppler imaging adds independent and incremental prognostic value. J Am Coll Cardio 2003, 41:820-826.

87. Choong CY, Herrmann HC, Weyman AE, Fifer MA: Preload dependence of doppler-derived indexes of left ventricular diastolic function in humans. J Am Coll Cardiol 1987, 10:800-808.

88. Dumesnil JG, Paulin C, Pibarot P, Coulombe D, Arsenault M: Mitral annulus velocities by doppler tissue imaging: practical implications with regard to preload alterations, sample position, and normal values. J Am SoC Echocardiogr 2002, 15:1226-1231

89. De las Fuentes L, Gu CC, Mathews SJ, Reagan JL, Ruthmann NP, Waggoner AD, Lai CF, Towler DA, Dávila-Román VG: Osteopontin promoter 
polymorphism is associated with increased carotid intima-media thickness. J Am Soc Echocardiogr 2008, 21:954-960.

90. Kleiger RE, Stein PK, Bigger JT Jr: Heart rate variability: measurement and clinical utility. Ann Noninvasive Electrocardiol 2005, 10:88-101.

91. Carney RM, Howells WB, Blumenthal JA, Freedland KE, Stein PK, Berkman LF, Watkins LL, Czajkowski SM, Steinmeyer B, Hayano J, Domitrovich PP, Burg MM, Jaffe AS: Heart rate turbulence, depression, and survival after acute myocardial infarction. Psychosom Med 2007, 69:4-9.

92. Marine JE, Watanabe MA, Smith TW, Monahan KM: Effect of atropine on heart rate turbulence. Am J Cardiol 2002, 89:767-769.

93. Mrowka R, Persson PB, Theres H, Patzak A: Blunted arterial baroreflex causes "pathological" heart rate turbulence. Am J Physiol Regul Integr Comp Physiol 2000, 279:R1171-R1175.

94. Stein PK, Barzilay JI, Chaves PH, Mistretta SQ, Domitrovich PP, Gottdiener JS, Rich MW, Kleiger RE: Novel measures of heart rate variability predict cardiovascular mortality in older adults independent of traditional cardiovascular risk factors: the cardiovascular health study (CHS). J Cardiovasc Electrophysiol 2008, 19:1169-1174.

95. Kop WJ, Stein PK, Tracy RP, Barzilay Jl, Schulz R, Gottdiener JS: Autonomic nervous system dysfunction and inflammation contribute to the increased cardiovascular mortality risk associated with depression. Psychosom Med 2010, 72:626-635.

96. Asmar R, Benetos A, Topouchian J, Laurent P, Pannier B, Brisac AM, Target R, Levy BI: Assessment of arterial distensibility by automatic pulse wave velocity measurement, validation and clinical application studies. Hypertension 1995, 26:485-490.

97. Wilkinson IB, Fuchs SA, Jansen IM, Spratt JC, Murray GD, Cockcroft JR, Webb DJ: Reproducibility of pulse wave velocity and augmentation index measured by pulse wave analysis. J Hypertens 1998, 16:2079-2084.

98. Freedland KE, Skala JA, Carney RM, Raczynski JM, Taylor CB, De Leon CF M, Ironson G, Youngblood ME, Krishnan KR, Veith RC: The depression interview and structured hamilton (DISH): rationale, development, characteristics, and clinical validity. Psychosom Med 2002, 64:897-905.

99. Kohout FJ, Berkman LF, Evans DA, Cornoni-Huntley J: Two shorter forms of the CES-D (center for epidemiological studies depression) depression symptoms index. J Aging Health 1993, 5:179-193.

100. Caspi A, Sugden K, Moffitt TE, Taylor A, Craig IW, Harrington H, McClay J, Mill J, Martin J, Braithwaite A, Poulton R: Influence of life stress on depression: moderation by a polymorphism in the 5-HTT gene. Science 2003, 301:386-389.

101. Schootman M, Andresen EM, Wolinsky FD, Malmstrom TK, Miller JP, Miller DK: Neighborhood conditions and risk of incident lower-body functional limitations among middle-aged African Americans. Am J Epidemiol 2006, 163:450-458.

102. Schootman M, Andresen EM, Wolinsky FD, Malmstrom TK, Miller JP, Yan Y, Miller DK: The effect of adverse housing and neighborhood conditions on the development of diabetes mellitus among middle-aged African Americans. Am J Epidemiol 2007, 166:379-387.

103. Gu CC, Flores HR, De Las Fuentes L, Davila-Roman VG: Enhanced detection of genetic association of hypertensive heart disease by analysis of latent phenotypes. Genet Epidemiol 2008, 32:528-538.

104. Rao DC: An overview of the genetic dissection of complex traits. Adv Genet 2008, 60:3-34

105. Rodin AS, Boerwinkle E: Mining genetic epidemiology data with bayesian networks I: bayesian networks and example application (plasma apoE levels). Bioinformatics 2005, 21:3273-3278.

106. Kim YH, Kim SH, Lim SY, Cho GY, Baik IK, Lim HE, Na JO, Han SW, Ko YH, Shin C: Relationship between depression and subclinical left ventricular changes in the general population. Heart 2012, 98:1378-1383.

107. lestra JA, Kromhout D, van der Schouw YT, Grobbee DE, Boshuizen HC, van Staveren WA: Effect size estimates of lifestyle and dietary changes on all-cause mortality in coronary artery disease patients: a systematic review. Circulation 2005, 112:924-934.

108. Carney RM, Freedland KE, Veith RC: Depression, the autonomic nervous system, and coronary heart disease. Psychosom Med 2005, 67(Suppl 1):S29-S33.

109. Barnes RF, Veith RC, Borson S, Verhey J, Raskind MA, Halter JB: High levels of plasma catecholamines in dexamethasone-resistant depressed patients. Am J Psychiatry 1983, 140:1623-1625.

110. Esler M, Turbott J, Schwarz R, Leonard P, Bobik A, Skews H, Jackman G: The peripheral kinetics of norepinephrine in depressive illness. Arch Gen Psychiatry 1982, 39:295-300.
111. Lake CR, Pickar D, Ziegler MG, Lipper S, Slater S, Murphy DL: High plasma norepinephrine levels in patients with major affective disorder. Am J Psychiatry 1982, 139:1315-1318.

112. Roy A, Pickar D, De Jong J, Karoum F, Linnoila M: Norepinephrine and its metabolites in cerebrospinal fluid, plasma, and urine. Relationship to hypothalamic-pituitary-adrenal axis function in depression. Arch Gen Psychiatry 1988, 45:849-857.

113. Siever LJ, Davis KL: Overview: toward a dysregulation hypothesis of depression. Am J Psychiatry 1985, 142:1017-1031.

114. Veith RC, Lewis N, Linares OA, Barnes RF, Raskind MA, Villacres EC, Murburg MM, Ashleigh EA, Castillo S, Peskind ER, Pascualy M, Halter JB: Sympathetic nervous system activity in major depression. Basal and desipramine-induced alterations in plasma norepinephrine kinetics. Arch Gen Psychiatry 1994, 51:411-422.

115. Wyatt RJ, Portnoy B, Kupfer DJ, Snyder F, Engelman K: Resting plasma catecholamine concentrations in patients with depression and anxiety. Arch Gen Psychiatry 1971, 24:65-70.

116. Dawson ME, Schell AM, Catania JJ: Autonomic correlates of depression and clinical improvement following electroconvulsive shock therapy. Psychophysiology 1977, 14:569-578.

117. Esler M, Jennings G, Korner P, Willett I, Dudley F, Hasking G, Anderson W, Lambert G: Assessment of human sympathetic nervous system activity from measurements of norepinephrine turnover. Hypertension 1988, 11:3-20.

118. Lahmeyer HW, Bellur SN: Cardiac regulation and depression. J Psychiatr Res 1987, 21:1-6.

119. Barton DA, Dawood T, Lambert EA, Esler MD, Haikerwal D, Brenchley C, Socratous F, Kaye DM, Schlaich MP, Hickie I, Lambert GW: Sympathetic activity in major depressive disorder: identifying those at increased cardiac risk? J Hypertens 2007, 25:2117-2124.

120. Linares OA, Jacquez JA, Zech LA, Smith MJ, Sanfield JA, Morrow LA, Rosen SG, Halter JB: Norepinephrine metabolism in humans. Kinetic analysis and model. J Clin Invest 1987, 80:1332-1341.

121. Task Force of the European Society of Cardiology and the North American Society of Pacing and Electrophysiology: Heart rate variability: standards of measurement, physiological interpretation and clinical use. Circulation 1996, 93:1043-1065.

122. Stein PK, Domitrovich PP, Hui N, Rautaharju P, Gottdiener J: Sometimes higher heart rate variability is not better heart rate variability: results of graphical and nonlinear analyses. J Cardiovasc Electrophysiol 2005, 16:954-959.

123. Bigger JT Jr, Fleiss JL, Steinman RC, Rolnitzky LM, Kleiger RE, Rottman JN: Frequency domain measures of heart period variability and mortality after myocardial infarction. Circulation 1992, 85:164-171.

124. Bigger JT Jr, Fleiss JL, Rolnitzky LM, Steinman RC: Frequency domain measures of heart period variability to assess risk late after myocardial infarction. J Am Coll Cardiol 1993, 21:729-736.

125. Kleiger RE, Miller JP, Bigger JT Jr, Moss AJ: Decreased heart rate variability and its association with increased mortality after acute myocardial infarction. Am J Cardiol 1987, 59:256-262.

126. Vaishnav S, Stevenson R, Marchant B, Lagi K, Ranjadayalan K, Timmis AD: Relation between heart rate variability early after acute myocardial infarction and long-term mortality. Am J Cardiol 1994, 73:653-657.

127. Rich MW, Saini JS, Kleiger RE, Carney RM, TeVelde A, Freedland KE: Correlation of heart rate variability with clinical and angiographic variables and late mortality after coronary angiography. Am J Cardiol 1988, 62:714-717.

128. Schmidt G, Malik M, Barthel P, Schneider R, Ulm K, Rolnitzky L, Camm AJ, Bigger JT Jr, Schomig A: Heart-rate turbulence after ventricular premature beats as a predictor of mortality after acute myocardial infarction. Lancet 1999, 353:1390-1396.

129. Barthel P, Schneider R, Bauer A, Ulm K, Schmitt C, Schomig A, Schmidt G: Risk stratification after acute myocardial infarction by heart rate turbulence. Circulation 2003, 108:1221-1226.

130. Ghuran A, Reid F, La Rovere MT, Schmidt G, Bigger JT Jr, Camm AJ, Schwartz PJ, Malik M, ATRAMI Investigators: Heart rate turbulence-based predictors of fatal and nonfatal cardiac arrest (the autonomic tone and reflexes after myocardial infarction substudy). Am J Cardiol 2002, 89:184-190.

131. De Geus EJ: Genetic pleiotropy in depression and coronary artery disease. Psychosom Med 2006, 68:185-186.

132. Nakatani D, Sato H, Sakata Y, Shiotani I, Kinjo K, Mizuno H, Shimizu M, Ito H, Koretsune Y, Hirayama A, Hori M, Osaka Acute Coronary Insufficiency Study Group: Influence of serotonin transporter gene polymorphism on 
depressive symptoms and new cardiac events after acute myocardial infarction. Am Heart J 2005, 150:652-658.

133. Dentino AN, Pieper CF, Rao MK, Currie MS, Harris T, Blazer DG, Cohen HJ: Association of interleukin- 6 and other biologic variables with depression in older people living in the community. J Am Geriatr Soc 1999, 47:6-11.

134. Kop WJ, Gottdiener JS, Tangen CM, Fried LP, McBurnie MA, Walston J, Newman A, Hirsch C, Tracy RP: Inflammation and coagulation factors in persons $>65$ years of age with symptoms of depression but without evidence of myocardial ischemia. Am J Cardiol 2002, 89:419-424.

135. Maes M, Bosmans E, De Jongh R, Kenis G, Vandoolaeghe E, Neels H: Increased serum IL-6 and IL-1 receptor antagonist concentrations in major depression and treatment resistant depression. Cytokine 1997, 9:853-858.

136. Miller GE, Freedland KE, Carney RM, Stetler CA, Banks WA: Cynical hostility, depressive symptoms, and the expression of inflammatory risk markers for coronary heart disease. J Behav Med 2003, 26:501-515.

137. Miller GE, Freedland KE, Carney RM, Stetler CA, Banks WA: Pathways linking depression, adiposity, and inflammatory markers in healthy young adults. Brain Behav Immun 2003, 17:276-285.

138. Miller GE, Freedland KE, Duntley S, Carney RM: Relation of depressive symptoms to C-reactive protein and pathogen burden (cytomegalovirus, herpes simplex virus, Epstein-Barr virus) in patients with earlier acute coronary syndromes. Am J Cardiol 2005, 95:317-321.

139. Shimbo D, Chaplin W, Crossman D, Haas D, Davidson KW: Role of depression and inflammation in incident coronary heart disease events. Am J Cardiol 2005, 96:1016-1021.

doi:10.1186/1471-2261-13-66

Cite this article as: Bruchas et al.: The St. Louis African American healthheart study: methodology for the study of cardiovascular disease and depression in young-old African Americans. BMC Cardiovascular Disorders 2013 13:66.

\section{Submit your next manuscript to BioMed Central and take full advantage of:}

- Convenient online submission

- Thorough peer review

- No space constraints or color figure charges

- Immediate publication on acceptance

- Inclusion in PubMed, CAS, Scopus and Google Scholar

- Research which is freely available for redistribution 